\title{
STUDY ON HISTOPATHOLOGICAL SPECTRUM OF FOLLICULAR CELL DERIVED THYROID DISEASES
}

\author{
Priya P. V1, Rosin George Varghese2, Elvin Merin Cherian³, Lillykutty Pothan ${ }^{4}$, Asha Joan Murali ${ }^{5}$ \\ ${ }^{1}$ Associate Professor [CAP], Department of Pathology, Government Medical College, Kottayam. \\ 2Junior Resident, Department of Community Medicine, Government Medical College, Kottayam. \\ 3Junior Resident, Department of Pathology, Government Medical College, Kottayam. \\ ${ }_{4}^{4}$ Additional Professor [CAP], Department of Pathology, Government Medical College, Kottayam. \\ 5Junior Resident, Department of Community Medicine, Government Medical College, Kottayam
}

\section{ABSTRACT}

\section{BACKGROUND}

In clinical practice, disorders of thyroid are common worldwide and incidence of which varies with geographical as well as nutritional factors. About twelve percent of Indian adults have palpable goitre. Nowadays, thyroidectomy is a routine surgical procedure offering the chances of cure to many patients having goitre.

Aim of the study is to find out the common indications of thyroidectomy in our centre and to study the frequency and histopathological spectrum of follicular cell derived lesions in thyroidectomy specimens.

\section{MATERIALS AND METHODS}

It is a record-based retrospective study conducted in a tertiary care teaching centre in central Kerala. All thyroidectomy specimens received in the Department of Pathology in our centre from January 2011 to December 2015 for histopathological study were included in this study. Lesions involving ectopic thyroid tissue were excluded. Data including patient's age, sex, type of surgery done and histopathological diagnosis were collected from the records and analysed by SPSS package 16.0.

\section{RESULTS}

The commonest indication for thyroidectomy in all age group was follicular cell derived lesions of thyroid. Frequency of foll icular cell derived lesions was $99.2 \%$ among thyroid specimens. Most common follicular cell derived lesion was multinodular colloid goitre. Papillary carcinoma was the commonest follicular cell derived malignant lesion of thyroid. Peak incidence of both neoplastic and non-neoplastic category of follicular cell derived lesions was noted in the age group of 40-49 years. Frequency of follicular cell derived lesions was significantly higher in females than males.

\section{CONCLUSION}

Current study showed comparatively higher prevalence rate of thyroid lesions and the peak incidence of follicular cell derived lesions in the age group of 40-49 years. This difference may be due to the influence of nutritional and environmental factors, so more observations and studies are warranted in this aspect.

\section{KEYWORDS}

Thyroid Disease, Thyroidectomy, Goitre, Follicular Cells.

HOW TO CITE THIS ARTICLE: Priya PV, Varghese RG, Cherian EM, et al. Study on histopathological spectrum of follicular cell derived thyroid diseases. J. Evolution Med. Dent. Sci. 2016;5(89):6626-6629, DOI: 10.14260/jemds/2016/1499

\section{BACKGROUND}

Thyroid gland is the largest of all endocrine glands. In clinical practice developmental, inflammatory, hyperplastic and neoplastic diseases of thyroid are common worldwide.[1] Thyroid diseases are of great importance, because most of them are amenable to medical or surgical management. According to a projection from various studies on thyroid disease, it has been estimated that about 42 million people in India suffer from thyroid diseases. [2] Hilly areas like Himalayan regions as well as coastal areas like Goa, Gujarat and Kerala are endemic for thyroid diseases. The government of India has

Financial or Other, Competing Interest: None.

Submission 03-10-2016, Peer Review 27-10-2016,

Acceptance 02-11-2016, Published 07-11-2016.

Corresponding Author:

Dr. Priya P. V,

Associate Professor [CAP],

Department of Pathology,

Government Medical College, Kottayam.

E-mail:drpvpriya@yahoo.com

DOI: $10.14260 /$ jemds/2016/1499

started universal iodisation of salt owing to the huge burden of thyroid diseases in the country.[3] Goitre refers to enlarged thyroid gland, which is a common surgical problem in tertiary care hospitals. Biosynthetic defects, iodine deficiency, autoimmune diseases and nodular diseases can lead to goitre, though by different mechanisms. It is reported that twelve percent of Indian adults have palpable goitre.[4] Nodular colloid goitre is estimated to affect at least 200 million people worldwide involving all races in all climates. Hashimoto's thyroiditis is reported about ten times more common in coastal areas of India.[5] Based on National Cancer Registry Program reports of India, the highest relative frequency of thyroid cancer was in Thiruvananthapuram. [2] Thyroid cancer accounts for about one percent of all malignancy in developed countries and thyroid carcinoma is the most common malignancy of the endocrine system. Carcinomas of follicular cell origin far outnumber those of para-follicular cell origin and non-epithelial malignancies. Incidence of papillary carcinoma of thyroid has increased worldwide.[6] Prevalence of different thyroid disease varies with geographical and nutritional factors. Nowadays thyroidectomy is a routine surgical procedure because of the introduction of safe 
anaesthesia, antiseptics, fine surgical instruments and developments of new techniques, offering the chances of cure to many patients.[7] Our study was aimed to find out the common indications of thyroidectomy in our centre and to study the frequency and histopathological spectrum of follicular cell derived lesions in thyroidectomy specimens.

\section{MATERIALS AND METHODS}

This is a retrospective study approved by Scientific Review Committee and Institutional Review Board and performed in a tertiary care teaching centre serving urban and rural population of central Kerala. All thyroidectomy specimens received for histopathological study and diagnosed in the Department of Pathology of our centre during a period of five years from January 2011 to December 2015 were included in this study. Lesions involving ectopic thyroid tissue were excluded. Data including patient's age, sex, type of surgery done and morphological diagnosis were collected from the records. The collected data were analysed by SPSS package 16.0. Statistical significances were calculated by Chi square test and $\mathrm{P}$ values $<0.05$ were considered statistically significant.

\section{RESULTS}

During the study period, a total of 60310 surgical specimens were received in the Department of Pathology of our centre and $3.6 \%$ of which was thyroid specimens. Table 1 shows the frequency of thyroid specimens in relation to total surgical specimens received each year.

\begin{tabular}{|c|c|c|c|c|c|c|c|}
\hline \multicolumn{2}{|c|}{ Year } & $\mathbf{2 0 1 1}$ & $\mathbf{2 0 1 2}$ & $\mathbf{2 0 1 3}$ & $\mathbf{2 0 1 4}$ & $\mathbf{2 0 1 5}$ & Total \\
\hline $\begin{array}{c}\text { Specimen } \\
\text { Number }\end{array}$ & Total & 10270 & 11200 & 12494 & 13073 & 13273 & 60310 \\
\hline & Thyroid & 361 & 437 & 455 & 412 & 495 & 2160 \\
\hline$\%$ & & 3.5 & 3.9 & 3.6 & 3.2 & 3.7 & 3.6 \\
\hline \multicolumn{7}{|c|}{ Table 1. Frequency of Thyroid Specimens } \\
\hline
\end{tabular}

Patients who underwent thyroidectomy belong to age ranging from 8 to 90 years (Table 2). The gender distribution was predominantly females, constituting $86.6 \%$ of total cases and male-to-female ratio was 1:6.4.

\begin{tabular}{|c|c|c|c|c|c|c|c|c|c|c|c|}
\hline \multirow{3}{*}{$\begin{array}{l}\text { Number } \\
\text { of Cases }\end{array}$} & \multicolumn{10}{|c|}{ Age in Years } & \multirow[b]{2}{*}{ Total } \\
\hline & $<10$ & $10-19$ & $29-29$ & $30-39$ & $40-49$ & $50-59$ & $60-69$ & $70-79$ & $80-89$ & $90-99$ & \\
\hline & 2 & 33 & 153 & 567 & 739 & 390 & 220 & 48 & 7 & 1 & 2160 \\
\hline$\%$ & 0.1 & 1.52 & 7.08 & 26.25 & 34.21 & 18.06 & 10.19 & 2.22 & 0.32 & 0.05 & 100 \\
\hline \multicolumn{12}{|c|}{ Table 2. Age Distribution of Thyroidectomy Cases } \\
\hline
\end{tabular}

Among the 2160 thyroid specimens majority were (79\%) total thyroidectomy specimens, followed by hemithyroidectomy $13 \%$, near total thyroidectomy $6 \%$, subtotal thyroidectomy and others together $2 \%$. Histopathological study showed follicular cell derived lesions (FCL) in 2142 (99.2\%) thyroid specimens that include 383 neoplastic and 1759 non-neoplastic lesions (Figure 1). Nonfollicular cell derived lesions (NFCL) were observed in 18 $(0.8 \%)$ thyroid specimens which include 10 para-follicular cell derived lesions, 4 lymphomas, 1 metastasis and 3 parathyroid lesions.

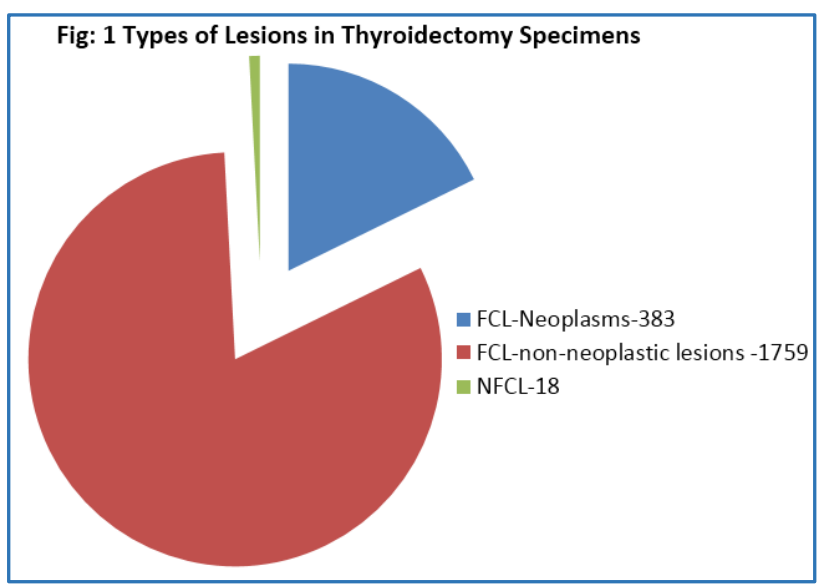

It is observed that prevalence rate of neoplastic FCL category starts increasing from 10 - 19 years of age group, then reaches maximum in the age group of 40 - 49 years and starts decreasing in the age group of 50 - 59 years, while prevalence rate of non-neoplastic FCL category starts increasing from 2029 years of age group and reaches maximum in the age group of 40 - 49 years, then starts decreasing in the age group of 50 59 years.

In our study, $60.6 \%$ of the total 2142 cases of follicular cell derived lesions belong to the age group of 30 to 49 years with a peak in the age group of 40 to 49 years. This value was found to be statistically significant with a Chi-square value of 99.327 at $\mathrm{P}<0.001$ (Table 3).

\begin{tabular}{|c|c|c|c|c|c|c|c|}
\hline \multirow[b]{2}{*}{$\begin{array}{l}\text { Age } \\
\text { in } \\
\text { Years }\end{array}$} & \multicolumn{3}{|c|}{ Neoplasm } & \multicolumn{3}{|c|}{ Non-Neoplastic Lesions } & \multirow[b]{2}{*}{$\begin{array}{c}\text { Total } \\
\text { No. }\end{array}$} \\
\hline & No. & $\begin{array}{c}\text { HP } \\
\text { Group } \\
\%\end{array}$ & $\begin{array}{c}\text { Age } \\
\text { Group } \\
\%\end{array}$ & No. & $\begin{array}{c}\text { HP } \\
\text { Group } \\
\%\end{array}$ & $\begin{array}{c}\text { Age } \\
\text { Group } \\
\%\end{array}$ & \\
\hline$<10$ & 1 & 0.2 & 50 & 1 & 0.1 & 50 & 2 \\
\hline $10-19$ & 16 & 4.2 & 50 & 16 & 0.9 & 50 & 32 \\
\hline $20-29$ & 52 & 13.6 & 34.4 & 99 & 5.6 & 65.6 & 151 \\
\hline $30-39$ & 91 & 23.8 & 16.1 & 473 & 26.9 & 83.9 & 564 \\
\hline $40-49$ & 96 & 25.1 & 13.1 & 639 & 36.3 & 86.9 & 735 \\
\hline $50-59$ & 56 & 14.6 & 14.5 & 331 & 18.8 & 85.5 & 387 \\
\hline $60-69$ & 46 & 12.0 & 21.2 & 171 & 9.7 & 78.8 & 217 \\
\hline $70-79$ & 22 & 5.7 & 46.8 & 25 & 1.4 & 53.2 & 47 \\
\hline $80-89$ & 3 & 0.8 & 50 & 3 & 0.2 & 50 & 6 \\
\hline $90-99$ & 0 & 0 & 0 & 1 & 0.1 & 100 & 1 \\
\hline Total & 383 & 100 & & 1759 & 100 & & 2142 \\
\hline
\end{tabular}

Prevalence of follicular cell derived lesions was significantly higher among females than males $(86.6 \%$ vs. $13.4 \%, \chi^{2}=4.56, \mathrm{P}=0.33$ ). It is also noted that male-to-female ratio was $1: 4.9$ and 1:6.9 in neoplastic and non-neoplastic categories respectively.

Among the thirteen different morphological types of follicular cell derived lesions observed in our study, the most 
common thyroid pathology was multinodular colloid goitre (63.6\%), which was followed by papillary carcinoma (Table 4).

\begin{tabular}{|c|c|c|c|c|c|}
\hline & Category & $\begin{array}{l}\text { HP Type } \\
\text { of FCL }\end{array}$ & Number & $\begin{array}{c}\text { Category } \\
\%\end{array}$ & $\begin{array}{c}\text { HP } \\
\text { Group } \\
\%\end{array}$ \\
\hline 1 & \multirow{6}{*}{$\begin{array}{l}\text { Neoplasms } \\
(\mathrm{n}=383)\end{array}$} & Adenoma & 107 & 28 & 5 \\
\hline 2 & & $\begin{array}{l}\text { Papillary } \\
\text { Carcinoma }\end{array}$ & 217 & 56.7 & 10.1 \\
\hline 3 & & $\begin{array}{l}\text { Follicular } \\
\text { Carcinoma }\end{array}$ & 46 & 12 & 2.1 \\
\hline 4 & & $\begin{array}{c}\text { Poorly } \\
\text { Differentiated } \\
\text { Carcinoma }\end{array}$ & 8 & 2.1 & 0.4 \\
\hline 5 & & $\begin{array}{l}\text { Undifferentiated } \\
\text { Carcinoma }\end{array}$ & 4 & 1 & 0.2 \\
\hline 6 & & $\begin{array}{l}\text { Squamous Cell } \\
\text { Carcinoma }\end{array}$ & 1 & 0.2 & 0.05 \\
\hline 7 & \multirow{7}{*}{$\begin{array}{c}\text { Non- } \\
\text { Neoplastic } \\
\text { Lesions } \\
(\mathrm{n}=1759)\end{array}$} & $\begin{array}{l}\text { Inflammatory } \\
\text { Lesions }\end{array}$ & 81 & 4.6 & 3.8 \\
\hline 8 & & $\begin{array}{c}\text { Diffuse } \\
\text { Hyperplasia }\end{array}$ & 1 & 0.1 & 0.05 \\
\hline 9 & & $\begin{array}{l}\text { Diffuse Colloid } \\
\text { Goitre }\end{array}$ & 4 & 0.2 & 0.2 \\
\hline 10 & & $\begin{array}{l}\text { Multi-Nodular } \\
\text { Colloid Goitre }\end{array}$ & 1362 & 77.4 & 63.6 \\
\hline 11 & & $\begin{array}{c}\text { Nodular } \\
\text { Hyperplasia } \\
\text { with Cellular } \\
\text { Nodule }\end{array}$ & 102 & 5.8 & 4.8 \\
\hline 12 & & $\begin{array}{l}\text { Solitary Cellular } \\
\text { Nodule }\end{array}$ & 48 & 2.7 & 2.2 \\
\hline 13 & & $\begin{array}{l}\text { Solitary Colloid } \\
\text { Nodule }\end{array}$ & 161 & 9.2 & 7.5 \\
\hline Total & 2142 & & 2142 & & 100 \\
\hline \multicolumn{6}{|c|}{$\begin{array}{l}\text { Table 4. Histopathological Spectrum of } \\
\text { Thyroid Follicular Cell Derived Lesions }\end{array}$} \\
\hline
\end{tabular}

Multicentricity of papillary carcinoma within the thyroid gland was seen macroscopically in 7 cases and microscopically in 24 cases. There were 8 cases of widely invasive follicular carcinoma and 38 cases of minimally invasive follicular carcinoma, four of which had morphology of minimally invasive Hurthle cell carcinoma. We observed 4 cases of undifferentiated carcinoma and 8 cases of poorly differentiated carcinoma in our study.

Second commonest lesion among non-neoplastic category was solitary colloid nodule (161 cases) and majority of which were managed by hemithyroidectomy. In 150 cases thyroid showed cellular nodule, either as a solitary lesion (48 cases) or as a part of nodular hyperplasia; 11 cases of cellular nodules had histopathological features of Hurthle cell nodule.

Inflammatory lesions were the indication for thyroidectomy in 81 cases which include 1 case of granulomatous thyroiditis $(1.2 \%), 17$ cases of lymphocytic thyroiditis (21\%) and 63 cases of Hashimoto thyroiditis (77.8\%). One of the Hashimoto thyroiditis case was clinically presented as multinodular goitre in a 47-year-old female. No developmental lesions were observed in our study.

\section{DISCUSSION}

Our retrospective study was performed using a database of 2160 thyroidectomy cases. Thyroid specimens constituted $3.6 \%$ of total surgical specimens received in the Department of Pathology of our centre during the study period. On comparing observations, the prevalence of thyroid lesions was found to be higher in our study (3.6\%) than that of Zulfikar et al[1] in Karnataka and Bharathidhasan et al[5] in Pondicherry (Table 5). This may be due to the influence of nutritional and environmental factors. We observed that majority of the patients in our study who underwent thyroidectomy were in the age group of 40-49 years, while in other studies[1,5] it was in the age group of $30-39$ years.

\begin{tabular}{|c|c|c|c|c|}
\hline \multicolumn{2}{|c|}{ Authors } & $\begin{array}{c}\text { Zulfikar } \\
\text { et al[1] }\end{array}$ & $\begin{array}{c}\text { Bharathi- } \\
\text { dhasan } \\
\text { et al[5] }\end{array}$ & $\begin{array}{c}\text { Present } \\
\text { Study }\end{array}$ \\
\hline \multirow{2}{*}{$\begin{array}{c}\text { Surgical } \\
\text { Specimens }\end{array}$} & Total & 6200 & 22676 & 60310 \\
\cline { 2 - 5 } Thyroidectomy & Thyroid & $1.6 \%$ & $1.8 \%$ & $3.6 \%$ \\
\cline { 2 - 5 } & Peak Age & $30-39$ & $30-39$ & $40-49$ \\
\hline \multirow{3}{*}{ FCL } & M:F & $1: 5.9$ & $1: 5.4$ & $1: 6.4$ \\
\cline { 2 - 5 } & Hevelopmental & $2 \%$ & $4.8 \%$ & Excluded \\
\cline { 2 - 5 } & Inflammatory & $10 \%$ & $11.4 \%$ & $4 \%$ \\
\cline { 2 - 5 } & Neoplasia & $31 \%$ & $35.8 \%$ & $18 \%$ \\
\hline
\end{tabular}

Table 5. Comparison of Follicular Cell Derived Lesions in Thyroidectomy Specimens with Other Studies

In the present study follicular cell derived lesions outstand (99.2\%) among the different types of thyroid lesions. Prevalence of FCL was high in the age group of 40 to 49 years, while it was in the age group of 30 to 39 years in other studies.[1,5] The prevalence of FCL was significantly higher among females. This corroborate the findings of Zulfikar et al[1] and Bharathidhasan et al[5] who have also reported similar finding.

Hyperplastic lesions predominate among the nonneoplastic category of FCL. Consistent with the observations of Zulfikar et al[1] and Bharathidhasan et al,[5] multi-nodular colloid goitre was the commonest (63.6\%) follicular cell derived lesion in our study. Various factors such as iodine deficiency, goitrogens, radiation, genetic factors and certain food items have been implicated for the development of multinodular goitre.[2,3 \& 8]

The second commonest FCL $(10.1 \%)$ in thyroid was papillary carcinoma, accounting for $57 \%$ of neoplastic category and $79 \%$ of malignant group. Deepa et al[9] in 2014 and Bharathidhasan et al[5] in 2015 reported that commonest thyroid malignancy in their study was papillary carcinoma, which was consistent with our observation. Papillary carcinoma often develops as multicentric tumour and such tumours are associated with increased risk of central and lateral neck lymph node involvement.[10] In our study multicentricity of papillary carcinoma within the thyroid gland was seen macroscopically in 7 cases. It is also documented that microscopic multicentricity of papillary carcinoma are found in about $20 \%$ of cases if a few random sections are taken and in over $75 \%$ if step sections of entire thyroid gland is examined.[8] In our study, microscopic multicentricity of papillary carcinoma within the thyroid gland was found in 24 cases $(11 \%)$. Controversy still exists as to whether this represents multicentricity or intrathyroidal lymphatic permeation. ${ }^{[8]}$

Follicular carcinoma contributed $2.1 \%$ of follicular cell derived lesions and $12 \%$ (46 cases) of the neoplastic lesions of thyroid. This group included 8 widely invasive neoplasms and rest were minimally invasive. Undifferentiated and poorly differentiated carcinomas of thyroid are considered as 
tumours of older age group. ${ }^{[8]}$ In our study also majority of these tumours were observed in older age group.

Inflammatory lesions accounted for 3.8\% of follicular cell derived lesions. Similar to other studies,[1\&5] among the different morphological types of thyroiditis the commonest indication for thyroidectomy was Hashimoto thyroiditis. In contrast to the usual pattern of diffuse symmetrical enlargement of thyroid gland, in some instances Hashimoto thyroiditis has a distinctly multinodular quality.[8] In our study, one of the 63 cases of Hashimoto thyroiditis had multinodular pattern of thyroid enlargement.

As lesions involving ectopic thyroid tissue were excluded, no cases belonging to developmental lesions were observed in our study. It is not possible to predict on the basis of morphologic appearance alone whether the patient has clinical evidence of hyperthyroidism, ${ }^{[8]}$ so functional status of thyroid lesions in the current study was not known.

\section{CONCLUSION}

It was a retrospective study approved by Scientific Review Committee and Institutional Review Board and carried out in a tertiary care teaching centre, which serves both urban and rural population of central Kerala. In this study, thyroid specimens accounted for $3.6 \%(n=2160)$ of total surgical specimens received over a period of five years. The commonest indication for thyroidectomy in all age group was follicular cell derived lesions of thyroid. Frequency of follicular cell derived lesions was $99.2 \%$ among thyroidectomy cases. Most common follicular cell derived lesion of thyroid was multinodular colloid goitre (63.6\%).(1,5,11-13) We observed a low incidence of thyroid neoplasms compared to other South Indian studies(1,5); however, consistent with other reports $(5,9,11,14,15)$ most common thyroid malignancy was $(79 \%)$ papillary carcinoma. Multicentricity of papillary carcinoma within the thyroid gland was seen macroscopically in 7 cases and microscopically in 24 cases. Frequency of follicular cell derived lesions was significantly higher in female gender with a male-to-female ratio of 1:6.5. Statistical analysis showed that in our study, thyroid lesions had a higher prevalence rate and the peak incidence of follicular cell derived lesions was in higher age group when compared to other studies.[1,5,12] This difference may be due to the influence of nutritional and environmental factors, so more observations and studies are warranted in this aspect.

\section{ACKNOWLEDGEMENT}

This study has been supported by the SBMR (State Board of Medical Research). We wish to especially acknowledge the support given to us by Dr. Latha V, Additional Professor, Department of Pathology, Govt. Medical College, Kerala.

\section{REFERENCES}

1. Zulfikar A, Ritica C, Umaru N. Study of prevalence of thyroid lesions in coastal regions of Karnataka. Journal of Evolution of Medical and Dental Sciences 2013;2:69957002.

2. Unnikrishnan AG, Menon UV. Thyroid disorders in India. An epidemiological perspective. Indian J Endocrinol Metab 2011;15(2):S78-S81.

3. Park K. Iodine deficiency disorders. In: Park K, editor. Park's text book of Preventive and Social Medicine, 23rd edn. Jabalpur:Banarsidas Bhanot; 2015. p. 643-644.

4. Menon UV, Sundaram KR, Unnikrishnan AG, et al. High prevalence of undetected thyroid disorders in an iodine sufficient adult south Indian population. Journal of Indian Medical Association 2009;107(2):72-7.

5. Bharathidhasan I, Goneppanavar M, Dhaka RS. Changing trends in the incidence of thyroid lesions in coastal regions of south India. Ind J Health Sci Res 2015;5(6):134-141.

6. DeLellis RA, Williams ED. Tumours of the thyroid and parathyroid. In: DeLellis RA, Lloyd RV, Heitz PU, et al. eds. World Health Organization Classification of Tumours. Pathology and genetics of tumours of endocrine organs. Lyon: IARC Press 2004:49-133.

7. Champa S, Tariq WK, Imrana Z, et al. Histopathological pattern of diagnoses in patients undergoing thyroid operations. Rawal Med J 2009;34(1):14-16.

8. Rosai J, Tallini G. Thyroid gland. In: Rosai J, editor. Rosai and Ackerman's surgical pathology, Volume 1, 10th edn. China:Elsevier; 2011. p. 500-515.

9. Kunjumon DT, Upadhyaya K. A clinicopathological audit of thyroid malignancies. A 2 year study. International Journal of Biomedical Research 2014;5(1):38-42.

10. Ju-Yeon K, Eun-Jung J, Sang-Ho J, et al. Clinical characteristics and prognosis of multifocal papillary thyoid carcinoma. J Korean Surg Soc 2010;79(6):442-446.

11. Pradeepkumar NS, Singh R, Joseph NM. Emerging trends in thyroid diseases in Tsunami hit coastal areas of Puduchery and Cuddalore, India. Journal of Evalution of Medical and Dental Sciences 2012;1(5):857-863.

12. Prajapati VP, Nayak JC, Desai KS, et al. Histological study of adenomatous goitre. National Journal of Integrated Research in Medicine 2012;3(2):65-8.

13. Antony J, Celine TM, Chacko M. Spectrum of thyroid disorders: a retrospective study at a medical college hospital. Thyroid Res Pract 2014;11(2):55-9.

14. Vanderpump MP. The epidemiology of thyroid disease. $\mathrm{Br}$ Med Bull 2011;99(1):39-51.

15. Nadeem K, Akhtar N, Tarar JM. Thyroid malignancy in multi nodular goiter; incidence, a retrospective study in southern Punjab. Professional Med J 2013;20(4):587-90. 